\title{
Plastic Pyrolisis of Low Density Polyethylene (LDPE) Using Bleaching Earth (BE) Catalyst Become Liquide Fuel
}

\author{
Sri Widya Astuti Abidin, Nurmalasari*, Ayu Ramadani, Sumiati, Ilmiati Illing \\ Department of Chemistry, University Cokroaminoto Palopo \\ *Corresponding Author: nur87.mipa@gmail.com \\ Received: January,01,2020 /Accepted:June,29,2020 \\ doi: 10.24252/al-kimiav8i1.10750
}

\begin{abstract}
This study aims to determine the effect of adding Bleaching Earth (BE) catalyst to the amount of liquid fraction by pyrolysis of LowDensity Polyethylene (LDPE) and find out the concentration of gasoline and diesel fractions from plastic pyrolysis Low density polyethylene (LDPE). The method in this study is the pyrolysis method (heating without oxygen) and analysis of the liquid fraction resulting from pyrolysis using GCMS (Gas Chromatrographic Mass Spectrometry). In this study, the effect of adding Bleaching Earth (BE) catalyst on Low Densiry Polyethylene plastic pyrolysis is the more catalyst used, the lower the quantity of liquid fraction. Based on GCMS analysis on plastic pyrolysis of Low Density Polyethylene (LDPE) from various variations of Bleaching Earth (BE) catalysts used the optimum concentration was obtained by adding $2.5 \mathrm{~g}, 5 \mathrm{~g}$, and $7.5 \mathrm{~g}$ Bleaching Earth (BE) catalysts to produce fractions higher diesel (C13C20), $37.04 \%, 31.04 \%$ and $35.59 \%$ respectively.
\end{abstract}

Keywords:LDPE, Bleaching Earth, Pyrolysis, GCMS.

\section{INTRODUCTION}

Plastic waste is one of the main problems faced today that can have a negative impact on human and the environment because of its non-biogradable nature. Plastic is a synthetic organic material or semi-synthetic organic material derived from petroleum and natural gas. Some synthetic plastic products such as polyethylene terephthalate (PET), high density polyethylene (HDPE), polyvinyl chloride (PVC), low density polyethylene (LDPE), polypropylene (PP), polystyrene (PS), polyurethane and polyphenols, produce plastic waste that is approximately - consists of $50-60 \%$ of PE, $20-30 \%$ of PP, 10-20\% PS and, 10\% PVC (Sarker, 2012; Sriningsih, et al. 2014; Miandad et al. 2017).

One method of processing plastic waste is by converting plastic waste into hydrocarbon fuels. This is because the plastic raw material is derived from petroleum derivatives so that it can be returned to hydrocarbons as an energy base material. Conversion of plastic waste can be done by cracking, which is the reaction of breaking C$\mathrm{C}$ bonds from long carbon chains and large molecular weights into short carbon chains with small molecular weights (Nurmalasari et al. 2016; Nurmalasari and Nur Afiah 2017).

Plastic waste needs to be developed into fuel as an alternative energy source. This has became very important because of the soaring world oil prices (Sharuddin et al. 2016). Pyrolysis can take place with or without a catalyst. The catalyst is used in the process because it can reduce temperatures reactions, and accelerate reactions, and produce products with more specific carbon atoms and lighter hydrocarbons (cwik 2014; Patni et al. 2013; Miandad et al. 2016). There are two kinds of catalytic cracking processes in treating plastic waste, namely using natural catalysts and synthetic catalysts. Examples of natural catalysts are silica-alumina, bentonite-clay, aluminum hydrosilicate while synthetic catalysts include silica-alumina, silica-magnesium, zeolite, activated carbon and alkali components (Kyaw and Hmwe 2015; Tan et al. 2018). 
Catalytic decomposition provides several advantages over thermal decomposition, namely decomposition takes place at lower temperatures, the resulting product is a hydrocarbon with a greater liquid fraction content and has a high catalyst selectivity. Plastic waste catalyst into liquid fuel is a silica-based catalyst (Miskolczi et al. 2009; Sharuddin et al. 2018).

The silica-based catalyst that is often found is bleaching eart (BE) or commonly also called bentonite. Based on the background above, the purpose of this study is to determine the effect of weighting the BE catalyst on the characteristics and quality of liquid fuel from low density plastic pyrolysis. Polyethylene (LDPE) and determine the concentration of petrol and diesel fractions resulting from pyrolysis of plastic Lowdensity Polyethylene (LDPE).

\section{RESEARCH METHOD}

\section{Materials and Tools}

In this research Low Density Polyethylene (LDPE) and Bleaching Eart (Taico brands) are used as materials, and the tools are GC-MS (QP2010SSHIMADZU) and Pyrolysator.

\section{Procedures}

\section{Sample Preparation}

The material used in this research is Low Density Polyethylene (LDPE) plastic waste. Plastic waste is cut with a small size then washed thoroughly and dried by aerated.

\section{Pyrolysis Process}

Put material into the reactor with a Low Density Polyethylene (LDPE) plastic composition with a Bleching Earth (BE) catalyst mixed. Perform pyrolysis with plastic ratio Low Density Polyethylene (LDPE): Bleaching Eart catalyst (BE) (P0 = 50 g: 0 g, P1 = 50 g: 2.5 g, P2 = 50 g: 5 g, P3 = 50 g: 7.5 g). The vapors from Low Density Polyethylene (LDPE) plastic decomposition will flow through vertical cooling to the reservoir.

\section{GC-MS Testing Stage}

The resulting oil is put into the beaker glass and added $\mathrm{Na}_{2} \mathrm{SO}_{4}$ anhydrate until saturated, then the beaker glass is closed tightly and allowed to stand for 24 hours, then the filtering process is carried out. The last, test was analyzed using GC-MS.

\section{RESULT AND DISCUSSION}

Based on research conducted on variations in weight of the catalyst to the characteristics of the liquid fuel from pyrolysis results obtained:

\section{Test Results of Effect of Catalyst Weight Variations on Reaction Time, Density, Quantity of Liquid Faction, Gas Quantity and Quantity of Charcoal.}

The time of pyrolysis reaction takes place quickly for mixture using catalyst while without catalyst requires a longtime reaction. Based on data on the liquid fraction quantity, charcoal quantity and gas quantity, the results are obtained that the liquid fuel with optimal results is in the BE $2.5 \mathrm{~g}$ mixture with a liquid fraction quantity value of $16.64 \%$, the value of the charcoal quantity is $36 \%$ and the quantity gas is $47.36 \%$. Then the less optimal results 
are in the mixture BE $7.5 \mathrm{~g}$ with a liquid fraction quantity value of $12.86 \%$, a charcoal quantity value of $68 \%$ and a gas quantity value of $19.14 \%$. The results of observations on the effect of variations in catalyst weight on reaction time, liquid fraction quantity, char quantity and gas quantity can be seen in table 1 .

Table 1. The effect of variations in catalyst weight on reaction time, quantity of liquid fraction, quantity of charcoal and gas quantity.

\begin{tabular}{cccc}
\hline BE $(\mathrm{g})$ & $\begin{array}{c}\text { Quantity of } \\
\text { Liquid Fraction } \\
(\%)\end{array}$ & Quanitity of Carchoal (\%) & $\begin{array}{c}\text { Quantity of Gas } \\
(\%)\end{array}$ \\
\hline 0 & $13.06 \%$ & $44 \%$ & $42,94 \%$ \\
2,5 & $16,64 \%$ & $36 \%$ & $47,36 \%$ \\
5 & $13,42 \%$ & $30 \%$ & $56,58 \%$ \\
7,5 & $12,86 \%$ & $68 \%$ & $19,14 \%$ \\
\hline
\end{tabular}

\section{GCMS Analysis}

Based on the GCMS test, the compound data contained in the liquid fraction of pyrolysis results were obtained. To facilitate the identification of what compound emerge from each peak, 5 (five) biggest or dominant compounds are taken by looking at 5 peaks with the largest $\%$ area of the chromatogram results. Compound data from GCMS test results can be seen in Tables 2, 3, 4 and 5 .

\section{BE 0 g (Without Catalyst)}

Table 2. GCMS Analysis Results Without Catalyst

\begin{tabular}{cccccc}
\hline Peak & $\begin{array}{c}\text { Retention Time } \\
\text { (minutes) }\end{array}$ & \% Area & Alleged Compound & $\begin{array}{c}\text { Quality } \\
(\%)\end{array}$ & $\begin{array}{c}\text { Molecular } \\
\text { Formula }\end{array}$ \\
\hline 2 & 2.116 & 5,88 & Acetone & 99 & $\mathrm{C}_{3} \mathrm{H}_{6} \mathrm{O}$ \\
21 & 37.516 & 5,32 & Isopropyl myristate & 92 & $\mathrm{C}_{17} \mathrm{H}_{34} \mathrm{O}_{2}$ \\
32 & 43.226 & 5,11 & $\begin{array}{c}\text { 10-Octadecenoic acid, } \\
\text { methyl ester }\end{array}$ & 93 & $\mathrm{C}_{19} \mathrm{H}_{36} \mathrm{O}_{2}$ \\
36 & 47.111 & 5,86 & $\begin{array}{c}\text { Methyl 12-hidroxy-9- } \\
\text { octadecenoate } \\
\text { Di-n-octyl phthalate }\end{array}$ & 89 & $\mathrm{C}_{19} \mathrm{H}_{36} \mathrm{O}_{3}$ \\
& 50.861 & 5,32 & 96 & $\mathrm{C}_{24} \mathrm{H}_{38} \mathrm{O}_{4}$ \\
\hline
\end{tabular}




\section{BE 2,5 gram Catalyst}

Table 3. GCMS Analysis Results BE 2,5 g Catalyst

\begin{tabular}{cccccc}
\hline Peak & $\begin{array}{c}\text { Reaction Time } \\
\text { (minutes) }\end{array}$ & \% Area & Alleged Compound & Quality (\%) & $\begin{array}{c}\text { Molecular } \\
\text { Formula }\end{array}$ \\
\hline 1 & 1.849 & 5,88 & Acetone & 99 & $\mathrm{C}_{3} \mathrm{H}_{6} \mathrm{O}$ \\
17 & 34.710 & 5,32 & Isopropyl Myristate & 92 & $\mathrm{C}_{17} \mathrm{H}_{34} \mathrm{O}_{2}$ \\
19 & 37.515 & 5,11 & $\begin{array}{c}\text { 10-Octadecenoic acid, } \\
\text { methyl ester }\end{array}$ & 93 & $\mathrm{C}_{19} \mathrm{H}_{36} \mathrm{O}_{2}$ \\
30 & 43.220 & 5,86 & $\begin{array}{c}\text { Methyl 12-hidroxy-9- } \\
\text { octadecenoate } \\
\text { Di-n-octyl phthalate }\end{array}$ & 89 & $\mathrm{C}_{19} \mathrm{H}_{36} \mathrm{O}_{3}$ \\
42 & 50.861 & 5,32 & & 96 & $\mathrm{C}_{24} \mathrm{H}_{38} \mathrm{O}_{4}$ \\
\hline
\end{tabular}

\section{BE 5 gram Catalyst}

Table 4. GCMS Analysis Result BE 5 g catalyst

\begin{tabular}{|c|c|c|c|c|c|}
\hline Peak & $\begin{array}{l}\text { Retention Time } \\
\text { (minutes) }\end{array}$ & $\%$ Area & Alleged Compound & Quality (\%) & $\begin{array}{l}\text { Molecular } \\
\text { Formula }\end{array}$ \\
\hline 1 & 1.946 & 6,79 & $\begin{array}{l}\text { 2,4-Dihydoxy-5- } \\
\text { nitropyrimidine }\end{array}$ & 63 & $\mathrm{C}_{4} \mathrm{H}_{3} \mathrm{~N}_{3} \mathrm{O}_{4}$ \\
\hline 11 & 37.516 & 17,40 & Isopropyl Myristate & 93 & $\mathrm{C}_{17} \mathrm{H}_{34} \mathrm{O}_{2}$ \\
\hline 16 & 43.338 & 8,36 & $\begin{array}{c}\text { 10-Octadecenoic acid, methyl } \\
\text { ester }\end{array}$ & 96 & $\mathrm{C}_{19} \mathrm{H}_{36} \mathrm{O}_{2}$ \\
\hline 17 & 43.726 & 5,28 & 2-Nonadecanone & 93 & $\mathrm{C}_{19} \mathrm{H}_{36} \mathrm{O}$ \\
\hline 27 & 50.863 & 9,05 & Di-n-octyl phthalate & 97 & $\mathrm{C}_{24} \mathrm{H}_{38} \mathrm{O}_{4}$ \\
\hline
\end{tabular}

\section{BE 7,5 gram Catalyst}

Table 5. GCMS Analysis Results BE 7,5 g Catalyst

\begin{tabular}{|c|c|c|c|c|c|}
\hline Peak & $\begin{array}{l}\text { Retention Time } \\
\text { (minutes) }\end{array}$ & $\%$ Area & Alleged Compound & Quality (\%) & $\begin{array}{c}\text { Molecular } \\
\text { Formula }\end{array}$ \\
\hline 13 & 37.519 & 16,37 & Isopropyl Myristate & 93 & $\mathrm{C}_{17} \mathrm{H}_{34} \mathrm{O}_{2}$ \\
\hline 17 & 43.228 & 7,90 & $\begin{array}{l}\text { 10-Octadecenoic acid, methyl } \\
\text { ester }\end{array}$ & 94 & $\mathrm{C}_{19} \mathrm{H}_{36} \mathrm{O}_{2}$ \\
\hline 18 & 43.341 & 4,89 & 2-Nonadecanone & 94 & $\mathrm{C}_{19} \mathrm{H}_{36} \mathrm{O}$ \\
\hline 24 & 47.105 & 6,43 & $\begin{array}{l}\text { Methyl 12-hydroxy-9- } \\
\text { octadecenoate }\end{array}$ & 90 & $\mathrm{C}_{19} \mathrm{H}_{36} \mathrm{O}_{3}$ \\
\hline 28 & 50.861 & 11,24 & Di-n-octyl phthalate & 96 & $\mathrm{C}_{24} \mathrm{H}_{38} \mathrm{O}_{4}$ \\
\hline
\end{tabular}




\section{Effect of catalyst weight variation on the quantity of liquid fraction}

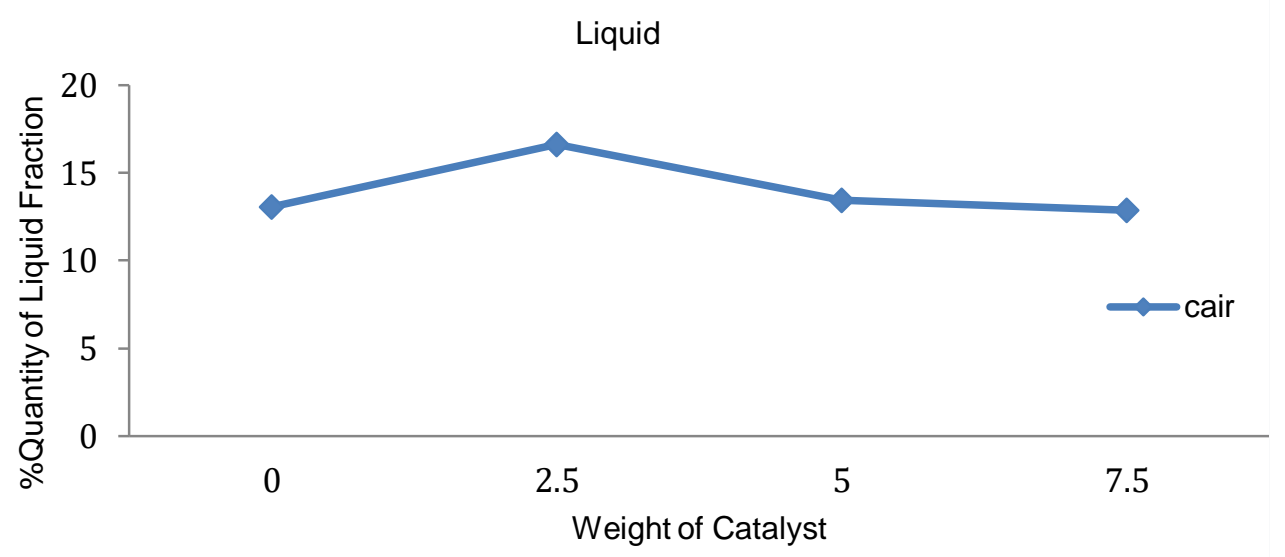

Figure 1. Comparison of Liquid Product Quantities

In figure 1 the highest liquid fraction product is achieved by a BE $2.5 \mathrm{~g}$ catalyst mixture that is $16.64 \%$. and the lowest liquid fraction product was achieved by a mixture of BE $7.5 \mathrm{~g}$ catalyst that was $12.86 \%$. The use of too much catalyst cause excessive catalytic cracking reaction resulting in reduced liquid fraction products resulting from cracking and increasing the quantity of gas and cocas produced (Syamsiro, Cheng, et al. 2014).

\section{Effect of catalyst weight variation on coke quantity}

The percentage of coke can be seen in Figure 2, where the percentage of charcoal continues to decrease, namely in the BE 0 g catalyst mixture by $44 \%$, BE $2.5 \mathrm{~g}$ catalyst mixture by $36 \%$ and BE 5 g catalyst mixture by $30 \%$.

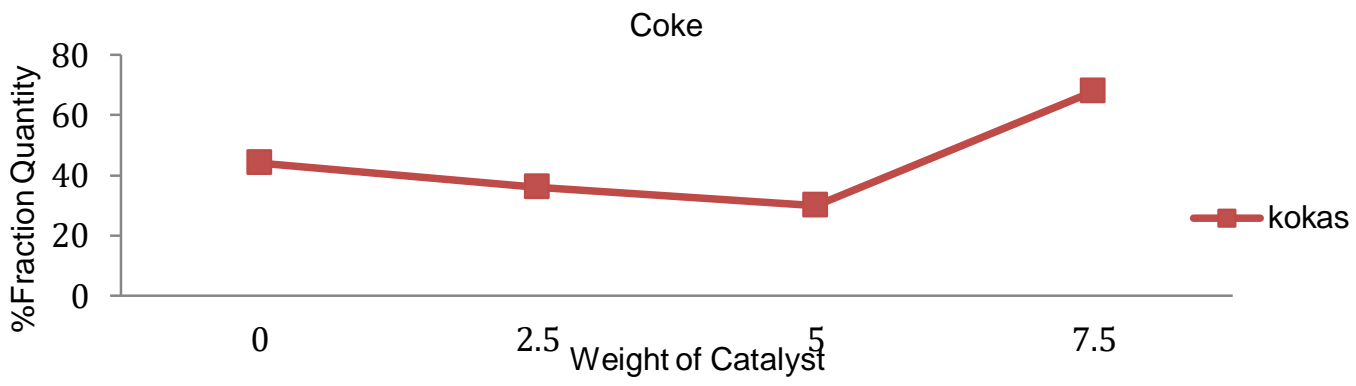

Figure 2. Comparison of Coke Product Quantities

However, the percentage of charcoal has increased in the BE $7.5 \mathrm{~g}$ catalyst mixture by $68 \%$. Catalysts with higher amounts can lead to the formation of relatively large quantities of coke (Nurmalasari et al. 2016). Coke is the organic matter left over from combustion of an organic material. Coke content is a part of the weight of the material based on its dry weight. Coke content is a physical property of the fuel that shows the amount of residue contained in the fuel expressed in percent. 


\section{Effect of catalyst mass variation on gas quantity}

The percentage of gas can be seen in Figure 9. Where the percentage of gas continues to increase, namely each in the BE $0 \mathrm{~g}$ catalyst mixture by $42.94 \%$, BE $2.5 \mathrm{~g}$ catalyst mixture by $47.36 \%$, and BE $5 \mathrm{~g}$ catalyst mixture by $56.58 \%$. However, the percentage of gas decreased in the BE $7.5 \mathrm{~g}$ catalyst mixture by $19.14 \%$.

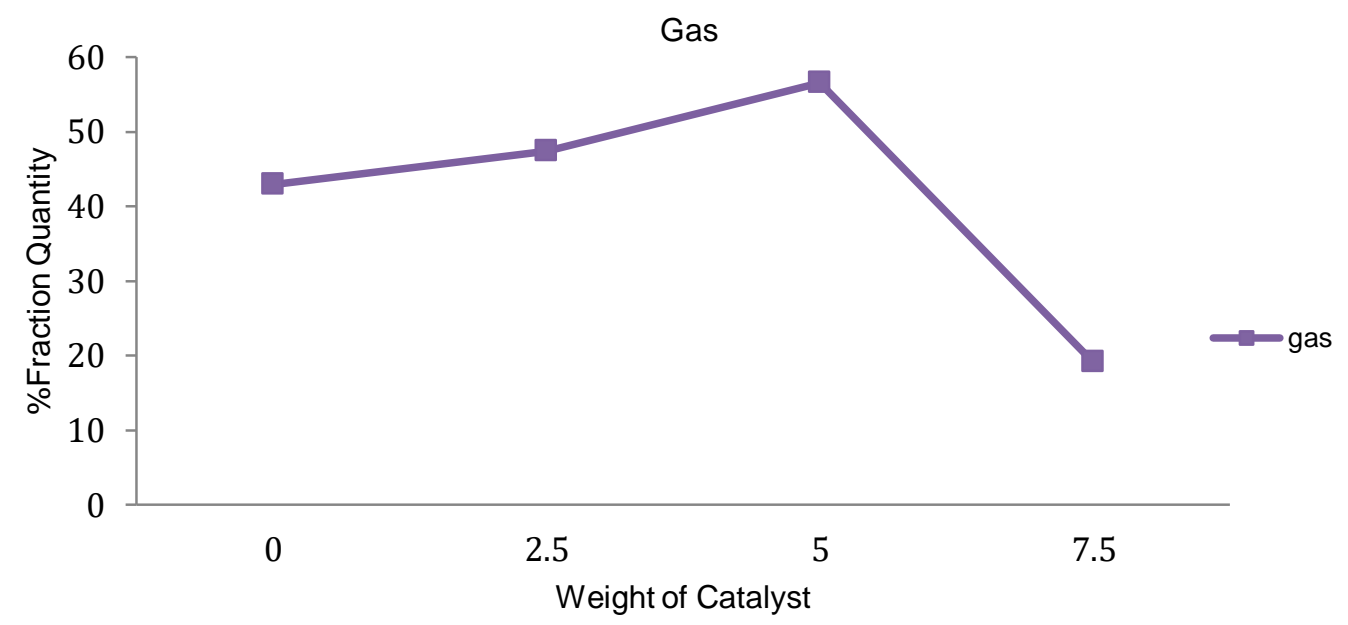

Figure 2. Comparison of Gas Product Quantities

It can be seen in figure 9 that the more catalyst used the smaller fraction of gas produced. This is due to the relatively long cracking time which has resulted in the repolymerization and condensation reaction.

The repolymerization reaction is the reverse reaction of the cracking reaction which also involves the carbonium ion, so that it can also accompany the cracking reaction. One example of the repolymerization reaction is the olefin polymerization reaction which is catalyzed by acid. As a result of the repolymerization reaction the resulting gas fraction is reduced because it has reacted to a heavier fraction. In addition, too much time results in the catalyst being deactivated by reactants and abundant products, so that it can cover the active site on the catalyst (Nurmalasari et al. 2016; Syamsiro, Cheng, et al. 2014).

\section{Liquid Fraction Content}

The liquid fraction of pyrolysis results was analyzed using GC-MS.Based on the chromatogram shown in Figure 10, it can be concluded that there are three types of liquid fraction containing pyrolysis. Gasoline fractions that can be identified at retention time limits are up to 20 minutes, diesel fuel 20-50 minutes and heavy oil fractions of more than 50 minutes (Nurmalasari et al. 2016). All compounds contained in the liquid fraction of pyrolysis have a range of $\mathrm{C} 13$ to $\mathrm{C} 19$ hydrocarbon bonds. Gasoline has a range of amounts of carbon from C5-C12, C13-C20 diesel and heavy oils> C20 (Syamsiro, Cheng, et al. 2014). Judging from the $\%$ Area in table 9 it can be seen that the largest solar fraction uses a $2.5 \mathrm{~g} \mathrm{BE}$ catalyst and the largest weight fraction uses a $7.8 \mathrm{~g} \mathrm{BE}$ catalyst in the pyrolysis process. 
Chromatogram data obtained as area were calculated as concentrations of gasoline, diesel and heavy oil fractions and are presented in table 9.

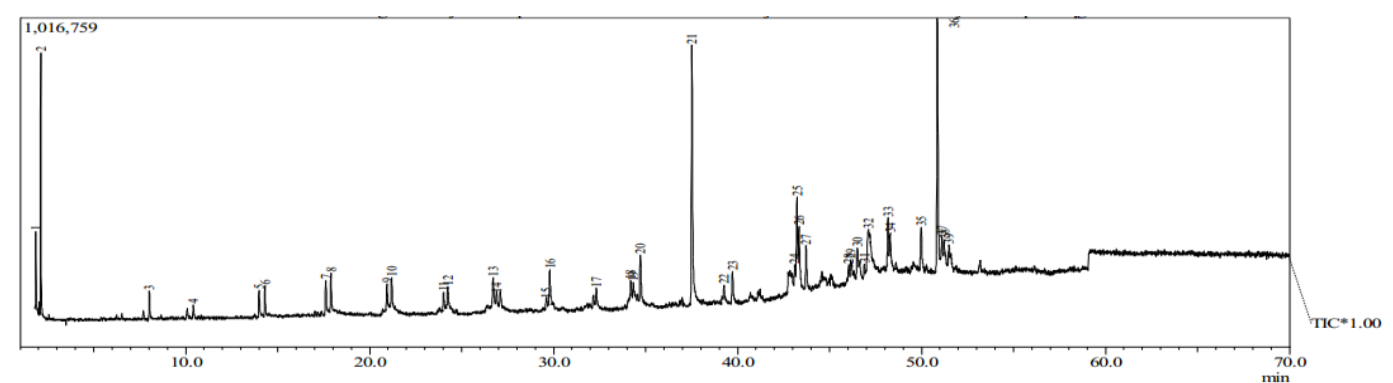

(a)

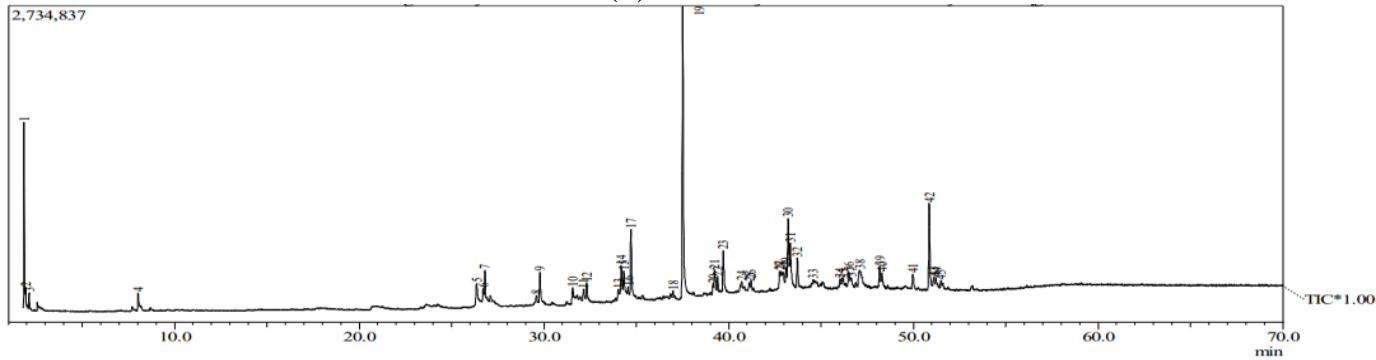

(b)

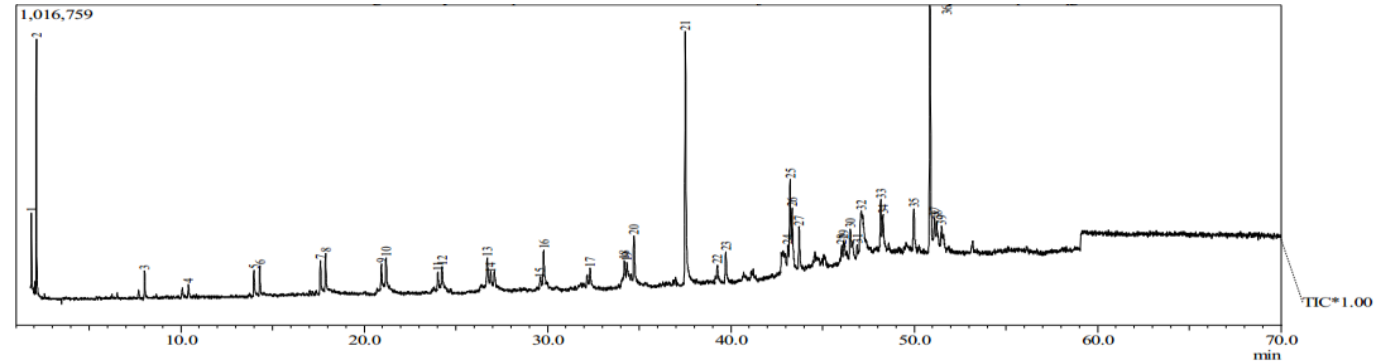

Figure 4. Cromatogram of Low Density Polyethylene Liquid (a) BE 0 g; (b) BE 2.5 g; (c) BE 5 g; (d) BE $7.5 \mathrm{~g}$

Table 6. Calculation of the total\% area

\begin{tabular}{ccccc}
\hline \multirow{2}{*}{ Carbon Range } & \multicolumn{4}{c}{ \% Total Area } \\
\cline { 2 - 5 } & \multirow{2}{*}{ BE 0 g } & BE 2,5 g & BE 5 g & BE 7,5 g \\
\hline $\mathrm{C}_{5}-\mathrm{C}_{12}$ & 17,11 & 8,59 & 6,97 & 4,90 \\
$\mathrm{C} 13-\mathrm{C} 20$ & 79,44 & 89,6 & 78,49 & 88,51 \\
$\mathrm{C} 21<$ & 3,45 & 1,81 & 14,72 & 6,59 \\
\hline
\end{tabular}

In plastic pyrolysis without the use of catalysts produce solar fractions and low weight fractions. It is thought to originate from the polymerization reaction of the hydrocarbon fraction with a smaller number of $\mathrm{C}$ atoms. The thermal cracking reaction has a low activity, due to the absence of compounds as hydrogen donors that play a role Al-Kimia|Volume 8 Nomor 1202061 
important in the initiation stage for the formation of carbonium ions. In the reaction thermally free radicals are formed which are very reactive, where these free radicals can react further with other free radicals or other molecules to become more stable molecules. The polymerization reaction occurs when there is a reaction between free radicals and carbon molecules that have double bonds so as to produce products with a greater number of C atoms (Syamsiro, Saptoadi, et al. 2014).

Based on the grouping of the 5 highest peaks of the liquid fraction chromatogram, the result of plastic pyrolysis of Low Density Polyethylene (LDPE) using Bleaching Earth (BE) catalyst is dominated by solar fraction and heavy fraction. This is because the Bleaching Eart (BE) catalyst has not been able to cut long chain hydrocarbons into short chain hydrocarbons.

Chromatograms from GC-MS analysis showed that the compounds contained in the liquid fraction of pyrolysis results were dominated by hydrocarbon compounds. The classification of hydrocarbon types contained in the liquid fraction of pyrolysis results can be seen in Table 10.

Table 7. Types of hydrocarbon bonds contained in the liquid fraction

\begin{tabular}{ccc}
\hline $\begin{array}{c}\text { Hydrocarbon } \\
\text { Bonds }\end{array}$ & Compound Name & Molecular Formula \\
\hline Keton & 2-Nonadecanone & $\mathrm{C}_{19} \mathrm{H}_{38} \mathrm{O}$ \\
& Isopropyl Myristate & $\mathrm{C}_{17} \mathrm{H}_{34} \mathrm{O}_{2}$ \\
& Methyl 12-hydroxy-9-octadecenoate & $\mathrm{C}_{19} \mathrm{H}_{36} \mathrm{O}_{3}$ \\
Ester & Di-n-octyl phthalate & $\mathrm{C}_{24} \mathrm{H}_{38} \mathrm{O}_{4}$ \\
& 10-Octadecenoic acid, methyl ester & $\mathrm{C}_{19} \mathrm{H}_{36} \mathrm{O}_{2}$ \\
\hline
\end{tabular}

Based on Table 10, the most dominant compounds contained in the liquid fraction of pyrolysis results are ketone and ester hydrocarbon compounds. This is due to the pyrolysis that uses plastic raw materials derived from fossil fuels or petroleum so that it contains many hydrocarbon compounds (Syamsiro, Saptoadi, et al. 2014)

The compounds produced from the hydrocracking process are found in the hydrocarbon groups of ketones and esters. The dominant compound is the ester group such as Isopropyl Miristat and Di-n-Octyl Phthalate since it has the highest selectivity when compared to other compounds in each catalyst peaks with different reaction times. Both of these compounds are likely to be produced due to the presence of gas which cannot be condensed during the pyrolysis process.

\section{CONCLUSION}

Al-Kimia|Volume 8 Nomor 1202062 
Based on the results of research conducted on pyrolysis of plastic Low Density Polyethylene (LDPE) using Bleaching Earth (BE) catalyst into liquid fuel, it can be concluded that the effect of the addition of Bleaching Earth (BE) catalyst on the pyrolysis of Low Density Polyethylene plastics is that the more catalyst used the lower the liquid fraction quantity and based on GCMS analysis on Low Density PolyEthylene (LDPE) plastic pyrolysis from various variations of Bleaching Earth (BE) catalyst used, the optimum concentration is obtained by adding $2.5 \mathrm{~g}, 5 \mathrm{~g}$ and $7.5 \mathrm{~g}$ Bleaching Earth catalysts. resulting in higher solar fractions (C13-C20) at $37.04 \%, 31.04 \%$ and $35.59 \%$, respectively. And does not produce gasoline fraction.

\section{ACKNOWLEDGMENT}

We would like to thank the Ministry of Research and Technology of Higher education (KEMENRISTEK DIKTI) who have funded our research to the end and thank you also to the supervisor lecturer Nurmalasari S, S.Si, M.Sc. who helps us to complete the research.

\section{REFERENCES}

Ćwik, Agnieszka. (2014). "Fuel from Waste - Catalytic Degradation of Plastic Waste to Liquid Fuels," 10.

Kyaw, Khaing Thandar, and Chaw Su Su Hmwe. (2015). "Effect Of Various Catalysts On Fuel Oil Pyrolysis Process Of Mixed Plastic Wastes" 8 (5): 794-802. https://doi.org/10.1016/j.rser.2015.10.015.

Miandad, R., M.A. Barakat, Asad S. Aburiazaiza, M. Rehan, A.S. Nizami. (2016). "Catalytic pyrolysis of plastic waste: A review." Process Safety and Environmental Protection 102: 822-838, https://doi.org/10.1016/j.psep.2016.06.022.

Miandad, R., M.A. Barakat, Asad S. Aburiazaiza, M. Rehan, I.M.I. Ismail, A.S. Nizami. (2017). "Effect of plastic waste types on pyrolysis liquid oil." International Biodeterioration \& Biodegradation 119: 239-252, https :/ /doi.org/ 10.10 16/ j.ibiod.2016.09.017.

Miskolczi, N., A. Angyal, L. Bartha, and I. Valkai. (2009). "Fuels by Pyrolysis of Waste Plastics from Agricultural and Packaging Sectors in a Pilot Scale Reactor." Fuel Processing Technology 90 (7-8): 1032-40. https://doi. org/10. 1016/j .fuproc.2009.04.019.

Nurmalasari and Nur Afiah. (2017). "Briket Kulit Batang Sagu (Metroxylon sagu) Menggunakan Perekat Tapioka dan Ekstrak Daun Kapuk (Ceiba pentandra)". Jurnal Dinamika 8(1).

Nurmalasari, Wega Trisunaryanti, Iip Izul Falah, and Sutarno. (2016). "Mesoporous Silica Impregnated by Ni and NiMo as Catalysts for Hydrocracking of Waste Lubricant" Int. J. ChemTech Res., 9 (9), 607-614. 
Patni, Neha, Pallav Shah, Shruti Agarwal, and Piyush Singhal. (2013). "Alternate Strategies for Conversion of Waste Plastic to Fuels." ISRN Renewable Energy 2013: 1-7. https://doi.org/10.1155/2013/902053.

Sarker, M. (2012). "Fractional Distillation Process Utilized to Produce Light Fractional Fuel from Low Density Polyethylene (LDPE) Waste Plastic." The Open Fuels \& Energy Science Journal 5 (1): 39-46. https://doi.org/ $10.2174 \quad / 187697$ $3 \times 01205010039$.

Sharuddin, S. D. A., F., Faisal Abnisa, Wan Mohd Ashri Wan Daud, Mohamed Kheireddine Aroua. (2016). "A review on pyrolysis of plastic wastes." Energy Conversion and Management 115: 308-326. https://doi.org/10.1016/ j.enconman.2016.02.037

Sharuddin, S. D. A., F. Abnisa, W. M. A. W. Daud, and M. K. Aroua. (2018). "Pyrolysis of Plastic Waste for Liquid Fuel Production as Prospective Energy Resource." IOP Conference Series: Materials Science and Engineering 334 (March): 012001. https://doi.org/10.1088/1757-899X/334/1/012001.

Sriningsih, W. Monica Garby Saerodji, Wega Trisunaryanti, Ria Armunanto, and Iip Izul Falah. (2014). "Fuel Production from LDPE Plastic Waste Over Natural Zaolite Supported Ni, Ni-Mo, Co, and Co-Mo Metals." Procedia Environmetal Sciences 20: 215-224.

Syamsiro, Mochamad, Shuo Cheng, Wu Hu, Harwin Saptoadi, Nosal Nugroho Pratama, and Kunio Yoshikawa. (2014). "Liquid and Gaseous Fuels from Waste Plastics by Sequential Pyrolysis and Catalytic Reforming Processes over Indonesian Natural Zeolite Catalysts.” Waste Technology 2: 8.

Syamsiro, Mochamad, Harwin Saptoadi, Tinton Norsujianto, Putri Noviasri, Shuo Cheng, Zainal Alimuddin, and Kunio Yoshikawa. (2014). "Fuel Oil Production from Municipal Plastic Wastes in Sequential Pyrolysis and Catalytic Reforming Reactors." Energy Procedia 47: 180-88. https://doi.org/10.1016/j.egypro.2014.01.212.

Tan, Y.L., A.Z. Abdullah, B.H. Hameed. (2018). "Catalytic fast pyrolysis of durian rind using silica-alumina catalyst: Effects of pyrolysis parameters." Bioresource Technology 264: 195-205. https://doi.org/10.1016/j.biortech.201 